\title{
Haberin Geleceği: Gazetelerle İlgili Bilgi Hizmetlerinin Yapılanması ve Kullanımı
}

\author{
The Future of News: Building and Using Information \\ Services in Connection with Newspapers
}

\section{H. İnci ÖNAL*}

\begin{abstract}
Öz
Araştırmanın amacı, haber sağlama hizmetlerinin bugününü ve geleceğini incelemektir. Gazete toplayan ve okurların gazete içeriklerine hızlı ve kolay erişimini sağlayan kütüphane ve arşivler, faaliyetlerini ve buna bağlı olarak deneyimlerini artırmaktadırlar. Bu araştırmanın ilk adımı olarak, görüşme ve yazılı anket teknikleriyle Ankara'da temsilcilikleri bulunan 6 ulusal gazetenin sorumlularına ulaşılmıştır. Güncel durum, verilen hizmetler, sorunlar ve iş planlarıly ilgili bilgi toplanmıştır. Yapılan değerlendirme, gazete bilgilerinin yaygınlaştırılmasında, gelişen bilgi teknolojilerinin kütüphanelere daha fazla görev yüklediğini göstermektedir.
\end{abstract}

Anahtar sözcükler: Haberler, Bilgi yönetimi, Gazeteler, Gazetecilik.

\begin{abstract}
The purpose of the present research is to specify the current stand and future of information services in providing news. Libraries and archives that collect newspapers, and supply services to let the readers to have quick and easy access to their contents, increase their activities and in conjunction to this, their experience. As an initial step of the present research, by methods of interviewing and administering questionnaires, Ankara branch office responsible of six nationwide distributed daily newspapers were investigated. Data were compiled about the present situation, provided services, problems to be confronted, and work plans. According to the evaluations, it seems that the developments in
\end{abstract}

`Doç.Dr.; Hacettepe Üniversitesi Edebiyat Fakültesi Bilgi ve Belge Yönetimi Bölümü 06800 Beytepe - Ankara (onal@hacettepe.edu.tr). 
information technologies would also impose important tasks to libraries in case of disseminating newspaper information.

Keywords: News, Information management, Newspapers, Journalism.

\section{Giriş}

Haber, yaşam içinde meydana gelen olaylar, kişiler, çeşitli oluşumlar hakkındaki en yeni ve ilgi çekici bilgi olarak düşünülmektedir. Haberin içerdiği bilginin olabildiğince nesnel, dengeli ve tarafsız özellikler taşıması beklenmektedir. Bunları sağlamada görev ve sorumluluk ilgili haberi hazırlayan gazeteciye, muhabire ve genel anlamda basın mensuplarına aittir. Haber; medya ve/veya kitle iletişim araçları olarak bilinen sözlü, yazılı, basılı, görsel metin ve imgeleri içeren çok geniş kapsamda yayınlanarak hedef kitleye ulaşmaktadır. Gazete, kitap, dergi, süreli yayın, broşür, film, radyo ve televizyon yayını, bilgisayar yazılımı, fotoğraf, video paketi, kaset, CD, ilan, İnternet başta olmak üzere iletişim araçları veya medya ürünleri haber özelliği taşıyan bilginin toplanmasını, yazılmasını ve/veya kaydedilmesini, düzenlenmesini ve dağıtılmasını sağlamaktadır. Güncel olarak hazırlanması beklenen haberler, yayınlandığında bireysel, toplumsal, siyasal, ekonomik, eğitimsel, kültürel, maddi, manevi ve benzeri çok değişik etkilere neden olmaktadır. Haberin değeri güncelliğiyle artarken, yeni haberler doğmakta ve haberle etkileşim sürmektedir. Toplumu bilgilendirme, bilinçlendirme ve kamuoyu oluşturma gerçekleşmektedir.

Haberin geleceği, haberin yayınlanmasının ardından gereksinim duyulduğu anda erişilebilir ve kullanılabilir biçime dönüştürülmesini sağlayan işlemlerin sonuçlandırılması olarak ifade edilmektedir. Habere yönelik bilgi hizmetlerinin düzenlenmesiyle gereksinim duyulduğunda bir gün önceki haberden yıllar öncesine ait habere değin inilebilmektedir. Kütüphaneler ve arşivler başta olmak üzere çeşitli bilgi merkezleri koleksiyonlarının önemli bir parçasını oluşturan medya ve/veya kitle iletişim araçlarında yer alan habere yönelik erişimi sağlamaları mümkün olmaktadır. Son yıllarda hızla yaygınlaşan teknolojik gelişmeler sayesinde haberler elektronik ortamda depolanmakta, erişilmekte ve kullanılmaktadır. Haberin geleceği, ondan her zaman yararlanmayı sağlayacak işlemlerden etkilenmektedir. Verilen hizmetler güncel haberler kadar, haberi besleyen geçmişe ait bilgilere de erişimli sağlamaktadır. 


\section{Araştırmanın Genel Özellikleri}

Bilgi ve belge yönetimi açısından, gerek kullanıcıların bilgi gereksinimi duydukları haberlere ulaştırılabilmesi, gerekse medya ürünleri kapsamındaki bilgi kaynaklarına dayanan geniş kapsamlı hizmetler verilmesini ilgilendiren araştırmaların yapılması büyük önem taşımaktadır. 1930'lu yıllardan bu yana gazetelerdeki haberlere ilişkin kupürler, fotoğraflar ve negatif filmler "morg" olarak adlandırılan bölümlerde bulundurulduğu bilinmektedir. Hizmet anlayışının gelişmesi yeniden yapılanma gereksinimini doğurarak "gazete kütüphanesi", "gazete arşivi", "gazete koleksiyonları" kütüphane türleri içinde haberi veya yayın türlerini öne çıkartan koleksiyonlar oluşturulmasını sağlamıştır.

Bu makale "haber" kavramından yola çıkarak, medya ürünlerinden biri olarak seçtiğimiz "gazetelerin" bilgi merkezlerinde sunulan bilgi ve belge hizmetlerini nasıl çeşitlendirdiğini ve belirtilen kapsamda "haberin geleceğini" nasıl biçimlendirdiğini ortaya çıkarmaktadır. Bir başka deyişle "gazetelere" yönelik olarak biçimlendirilen bilgi ve belge hizmetlerinin genel özelliklerini tanımlarken, haberin de geleceğini görmeyi amaçlamaktadır.

Araştırmamızda betimleme yöntemi kullanılmıştır. Bu yöntemle çalışmalarımıza temel kazandırmak ve daha önce yapılan çalışmaları değerlendirmek istenmiştir. Çalışmanın başlangıcında "haber, gazetecilik, medya, kitle iletişim araçları, gazete kütüphanesi, gazete arşivi, gazete kupürleri, bilgi merkezlerinde gazetelere yönelik hizmetler" olmak üzere değişik başlıklar altında yabancı ve Türkçe kaynaklardan literatür taramaları yapılmıştır. Söz konusu kaynaklar arasında şunlar bulunmaktadır: International Federation of Library Associations and Institutions (IFLA). Newspapers Section. Newsletters (1993- ), Library and Information Science Abstract (1969- ), ProQuest Dissertations and Thesis (1980- ), Türkiye Bibliyografyası (1935- ) ve Türkiye Makaleler Bibliyografyası (1952-).

Ayrıntılı literatür taramasıyla erişilen kaynaklar incelenmiştir. 1980'li yılların sonundan itibaren bağımsız bir çalışma alanı olarak önem kazanan gazetecilikte bilgi merkezlerine ve hizmetlerine ilişkin saptanan durum açıklanmıştır. Gazete koleksiyonu olan bilgi merkezlerinde geliştirilen çalışmalar tanımlanmıştır. Yaptığımız araştırmalar sonucunda bilgi merkezlerinin habere, gazetelere, gazeteciliğe ve gazetecilere / basın mensuplarına yönelik hizmet alanları saptanırken, çeşitli uygulama örnekleri verilmektedir. Betimleme yöntemi doğrultusunda 
görüşmelerimiz, altı gazetenin Ankara'daki bilgi merkezi olarak adlandırılan birimlerini kapsar nitelikte, Aralık 2006 ve Ocak 2007 tarihlerinde gerçekleştirilmiştir. Bilgi merkezlerinden sorumlu görevlilere yönelik görüşmelerle bilgi merkezlerinin varlığı ve hizmetleri saptanmış, mevcut durumlar, koşullar ve özellikler aynen ortaya koymaya çalışımıştır. Gazetelere ve haberlere yönelik bilgi ve belge hizmetlerini bütünleştirerek özel çalışma alanları düzenleyen International Federation of Library Associations and Institutions (IFLA) tarafından gerçekleştirilen uygulamalar tanıtılmıştır. Güncel durum, sorunlar, uluslararası çalışma planları ve gerçekleştirdiğimiz araştırma çerçevesinde yapılan değerlendirmelerle sonuca varılmaktadır.

\section{Haber ve Gazetelere Haber Sağlayan Kaynaklar}

En önemli özelliği güncellik olan haberin doğru ve ilgi çekici yapısında anlattığı konular olay, fikir veya sorun hakkındadır. Mümkün olduğunca büyük hedef kitleye aktarılacaklar özetlenerek ve kurgulanarak sunulmaktadır. Tokgöz (2006, s. 129) tarafından yapılan değerlendirmeye göre: "haber her ne kadar bugünü, biraz geçmişi gösterse de daha çok gelecekle ilgilidir ve saatler hatta dakikalar içinde bozulup değerini ve önemini yitirmektedir."

Önemli kitle iletişim araçlarından biri olan gazete, değişik kaynaklardan elde edilen her çeşit bilgiyi toplamak, depolamak ve dağıtmak için kullanılmaktadır. Gazete, olaylardan toplumu haberdar etmek, kamuoyunu düzenlemek, yönetici otoriteleri uyarmak, eğitmek, eğlendirmek gibi çeşitli amaçlar taşıyarak belirli okuyucu kitlesine, belirli aralıklarla ve sürekli olarak ulaşan kitle iletişim aracıdır (Bodur, 1997, s. 5; İnuğur, 2002, s. 11).

Gazeteler temelde iki tür haber kaynağına sahiptir, bunlar:

1. Habere, olaya gazetecilerin-muhabirlerin tanıklık ettiği veya haber kaynağı kişiyle yapılan görüşmelerle elde edilen birinci el kaynaklar;

2. Haber ajansları ve yapılan araştırmalar başta olmak üzere basın bültenleri, açıklamalar, çeşitli kuruluşların belgeleri ve verilerden meydana gelen ikinci el kaynaklardır (Yüksel ve Gürcan, 2001, ss. 60-62; 69).

Bu kapsamda, haberin özelliklerinden dolayı farklılık göstermekle birlikte, gazetelere haber sağlayan kaynaklar ve bu kaynakların temel özellikleri şunlardır: 
1. Muhabirler: Belli bir gazete adına sorumlu oldukları bölgede veya konuda meydana gelen olayları yerinde görerek, gözlemleyerek, kaydederek ve anlatarak haber olarak sunan gazetecilerdir. Haber değeri olan olaylar muhabirler tarafından aktarılırken belli bir düzene uyum sağlamaya çalışılır. Kısaca $5 \mathrm{~N} 1 \mathrm{~K}$ olarak adlandırılan ve haberin giriş öğesini oluşturan bu unsurlar haberi oluşturan olayla ilgili "ne, nerede, ne zaman, neden, nasıl ve kim" sorularına yanıt verir. Haber değeri olabilecek olayların araştırılmasında muhabirlerin gerçeklere ve açıklayıcı bilgilere ulaşması kadar, geçmişe ait bilgileri elde etmesi de büyük önem taşımaktadır. Bu aşamada muhabirlerin haberle ilgili kaynakları elde edebilecekleri kütüphaneler ve arşivler devreye girmektedir (Campbell, 1997, s. 2; Tokgöz, 2006, ss. 132-155).

2. Haber ajansları: Meydana gelen olaylar sonucu ilgi çekeceği düşünülen binlerce haberin ajans editörüne gönderilmesinin ardından, haber niteliğinde olacakları önce değerlendiren, düzenleyen, gerekli ekleme ve çıkartmaların ardından son haline getirilen haberleri onaylayarak gazetelere dağıtan kuruluşlardır. Her bölgede muhabir bulundurması mümkün olmayan gazeteler için önemli haber kaynağı olmakla birlikte, genellikle birçok gazete tarafından yaygın kullanımları mevcuttur. Abone bedeli ödeyerek veya ilgili ajanslara ortak olarak yararlanılmaktadır. İletişim teknolojilerinin kullanılması muhabir - ajans - gazete arasında yoğun ve hızlı haber akışını sağlayan iletişim ağının kurulmasına yardımcı olmaktadır (Gaillard, 1991, ss. 43-44; Gamble ve Gamble, 1989, ss. 95-96).

1. Araştırmalar: Muhabirin yazacağı haberle ilgili derinlemesine bilgileri, açıklamaları ve değerlendirmeleri kapsayan ürünler ortaya çıkartmak üzere yapılan geniş kapsamlı çalışmalar bütünüdür. Bir olayın haber olabilmesi için öncesi, o andaki durumu ve sonrasında ortaya çıkabilecek sonuçlar birlikte değerlendirileceğinden yapılacak araştırmalar büyük önem kazanmaktadır. Araştırmalarla bütünleşen yorumlar haberlere anlam kazandıran en önemli öğelerin başında gelmektedir. Bilgi ve belge merkezleri araştırmaların yapılmasını sağlayan bilgi kaynaklarına ve belgelere yönelik hizmetlerin verilmesini sağlamaktadır. Gazetelerin bünyesinde kurulan kütüphaneler, arşivler ve kupür koleksiyonları araştırmaların yapılmasını ve 
haberlerin, özellikle araştırmaya dayanan haberlerin hazırlanma sürecini olumlu yönde etkilemektedir. Bu merkezlerin sağladığı hizmetler sayesinde gerçeklerin görülerek, olaylara farklı bakış açılarının yakalanması mümkün olmaktadır (Adil, 1991, s. 24; Gamble ve Gamble, 1989, ss. 97 98; Tokgöz, 2006: 281-282).

1800 'lerden itibaren yayınlanan New York Herald, New York Times ve New York Tribune gibi gazeteler danışma eserleri, kupürler ve fotoğraflardan oluşan bilgi kaynaklarını kapsayan kütüphanelerini oluşturmaya başlamışlardır. 1900'lerin ilk yarısındaki siyasi ve ekonomik gelişmeler gazetelerin nitelikli haber anlayışlarını geliştirmelerini gündeme getirirken, gazete kütüphaneleri de hazırladıkları geriye dönük kupür indeksleri ve biyografik kaynakların üretilmesiyle ait oldukları gazetelerde başlayan hizmet kalitesini yükseltme çalışmalarını desteklemişlerdir (Semonche, 1998).

\section{Gazetecilikte Bilgi Erişim Kaynakları}

Gazetelerin sağlanmasının ardından depolama, koruma ve erişimle ilgili olarak kullanılan kaynaklar teknolojik gelişmeler ışığında çeşitlenmiştir. Tarih boyunca başlıca bilgi erişim kaynakları arasında yer alanlar aşağıdadır:

Basılı Kaynaklar: Gazetelerin kupürler halinde kesilerek dosyalanmasıyla hazırlanmışlardır. Yerel, bölgesel, kişisel, toplumsal ve çeşitli konulara ilişkin haberlere yönelik erişim yolları aranmıştır. Konu sınıflaması, dizinleme, dosyalama ve sürekli güncelleme işlemleri gazete haberlerine erişimde kullanılan temel yöntemler olmuştur. Gazete kütüphaneleri kendi çalışanlarından çok dışarıdaki araştırmacıların kullanımlarını düşünerek kişi, konu ve yer adı gibi öğeleri kullanarak indeksler hazırlamışlardır. London Times gazetesi 1790'lara kadar geriye giderek ve değişik dönemlerde yukarıda sayılan farklı öğeleri kullanarak dizinleme yapmıştır (Semonche, 1998).

> Mikroformlar: 1938 yılında Harvard Üniversitesi tarafından yabancı gazetelere yönelik mikrofilm projesiyle başlayan çalışmalar 1950'lerden sonra yaygınlık kazanmıştır (Folcarelli, 1982, s. 5). Okunabilmeleri için gereken donanım belli miktarda maliyet gerektirse de, gazetelere yönelik orijinal görüntülerin elde edilmesi, saklanması, yer sorununun çözümlenmesi, eski yıllara 
ait bilginin korunması, kopyalar elde edilmesi mümkün olmaktadır. Başta mikrofilmler olmak üzere, bilgisayar ortamı kullanılarak çeşitli biçimlerde küçültülmüş görüntülerin basılmasıyla veya kapsanmasıyla hazırlanan mikroformlar (Computer Output Microform-COM ve Computer Input Microform-CIM) bilgi depolamayı kolaylaştırmıştır. Bilgi erişimde kullanılan sistemler (Computer Assisted Retrieval-CAR) yardımıyla dizinleme programlarının geliştirilmesi kullanım kolaylığını artırmıştır (Folcarelli, 1982, ss. 10-12; Smith, 1995, ss. 282-283).

$>$ İnternet ve Veri Tabanları: Geleneksel kütüphane koleksiyonları kadar bilgisayar ortamında depolanan kupürler gazetelerin bilgi merkezleri için önemli bilgi kaynaklarıdır. 1960'ı yıllarda başlayan çalışmalar, 1974'te New York Times Infobank'ın önce çevrimiçi haber özetlerini vermesiyle yeni bir boyut kazanmış, 1980'dan itibaren de tam metin ulaşımını gerçekleştirmesiyle hedefe ulaşıımıştır. Bilgi arama sürecini kısa süreye sığdırmayı başarabilen İnternet ve veri tabanları yardımıyla tam metin haberlere, özetlere, bibliyografik bilgilere, gazetelerin herhangi bir tarihte yapılmış baskısındaki metinlere ve çeşitli bilgi kaynaklarına erişim sağlanmaktadır. Literatürde yapılan araştırmalara göre gazetelerin üye olduğu veri tabanları arasında şunlar bulunmaktadır (Garrison, 1998; IFLA, 2007a; Krumenaker, 2000; Special Libraries Association, 2007):

Dow Jones Interactive: Bütün dünyadan 200'e yakın gazeteyi taramakla birlikte, çok sayıda dergi ve haber ajansının güncel olduğu kadar arşiv bilgilerine de erişim imkânı vermektedir.

LEXIS / NEXIS: 1973 yılında hukuk alanında veri tabanları oluşturmayla başlayan hizmetler, 1979 yılında çok sayıda gazeteyi, dergiyi, haber ajanslarını, ticari belgeleri ve ekonomi bilgilerini içerecek şekilde genişleyerek, 1994 yılından itibaren de Web üzerinden tarama imkânı sunulur hale getirilmiştir. Taramalar "NEWS Library" adı altında düzenlenen hizmetler yardımıyla verilmektedir. Yaklaşık 150 gazete tam metin olarak taranmakta olup farklı formatlar yardımıyla kullanıcıya tercih imkânları sunulmaktadır.

PAPERS ve PAPERSNU: Dialog tarafından sunulan veri tabanları olup 100 civarında gazeteyi içermektedir. Çevrimiçi erişime ek 
olarak Web üzerinden de erişim sağlanmaktadır. Geliştirdiği coğrafi bölümleme yardımıyla güncel ve geriye dönüşümlü ayrıntılı taramalar yapılabilmektedir.

VU / TEXT: Çeşitli amaçlarla 1970 yılında kurulmuştur. 1982 yılından itibaren gazetecilere yönelik elektronik kütüphane düşüncesinin ve diğer gazetelerin arşivlerine erişim isteğinin uygulamalara dönüşmeye başlaması yapılan çalışmalara yeni boyutlar kazandırmıştır. 1996 yılından sonra Kuzey Amerika kıtasında yayınlanan 100 'e yakın gazete ve haber ajansına erişim sağlamakla birlikte değişik başlıklarda tarama imkânları da sunmaktadır.

GARILDI: Açık adı "Gazete Arşiv ve İletişim Dizgesi Projesi" olan GARILDI Türkiye'de sayısal ortamda gerçekleştirilen planlı ilk çalışma kapsamında Boğaziçi Üniversitesi ve Aybim Bilgisayar Ticaret Limited Şirketi tarafından kurulmuştur. 1997 yılında Sabah gazetesine yönelik başlayan çalışmalar, kapsamını genişleterek önemli ilerlemeler göstermiştir. Gazete arşivleriyle birlikte haber başlığı, metin, resim, alt yazı ve benzeri haber unsurlarını içeren veri tabanlarını oluşturmaktadır. GARILDI, kapsamını genişletirken erişimi kolaylaştıran yöntemler üzerine çalışmalarını sürdürmektedir (GARILDI, 2007).

HABERBANK: Türkiye'nin ilk basın indeksi ve haber veri tabanıdır. 1988-1995 yılları arasında yayınlanmıştır. Türkiye'ye ait haber rehberi hazırlama amacıyla belli gazeteler seçilmiş; OcakAralık ayları arasını kapsar şekilde yıllık olarak düzenlenmiş; kişiler, kurumlar ve olaylar alfabetik sırada haber özetleri şeklinde sunulmuştur. Köşe yazıları, magazin haberleri ve spor haberleri konusunda çok seçici davranılarak kapsama dâhil edilmiştir. Yıllık her cildin sonuna dizin eklenmiştir (Haberbank, 1988; Haberbank, 1995). 1995 yılından günümüze haber veri tabanı halinde hizmetlerini sürdürmektedir (Haberbank, 2007).

\section{Bilgi Merkezlerinde Gazetelere Yönelik Hizmetler}

Betimleme yöntemi doğrultusunda yaptığımız araştırmalar sonucunda bilgi merkezlerinin habere, gazetelere, gazeteciliğe ve gazetecilere/basın mensuplarına yönelik hizmet alanları saptanarak aşağıda açıklanmıştır. 
Bir başka deyişle, "bilgi merkezlerinde gazetelere yönelik hizmetler" ve çeşitli örnekler ortaya çıkarılmıştır.

\section{Gazetecilerin Bilgi Gereksinimleri ve Bilgi Arama Davranışları}

Gazetecilerin bilgi gereksinimleri uzmanlık alanlarına, ilgilendikleri haber türünün özelliğine, çalıştıkları gazeteye, görevlendirildikleri birime ve ortamdaki gelişmelere göre değişmektedir. Gazeteci için bilgiye en kısa zamanda ulaşmak önemli olduğundan bilgi arama davranışları da zaman, yer ve eğitim çerçevesinde belirlenmektedir. Bu konuda yapılan araştırma örneklerinden bazıları şunlardır:

Gazetecilerin bilgi gereksinimleri ve bilgi arama davranışları konusunda ilk araştırmalardan birini gerçekleştiren Herron (1986), gazetecilerin yazdıkları temel haber alanlarına yönelik bilgiye gereksinim duyduklarını belirleyerek kişisel iletişime dayanan görüşmelerin ve kurum içinde kolay ulaşılabilen bilgi kaynaklarının tercih edildiğini saptamıştır. Gelecekte elektronik ortamdan ulaşılabilen bilgi kaynaklarıyla bilgi arama davranışlarının yeniden biçimleneceğini tahmin etmiştir.

Ward, Hansen ve McLeod (1988) araştırmalarında bir haber veya konuyla ilgili geçmişe yönelik temel bilgi isteği duyan gazetecilerin genellikle konu alanlarını belirledikleri, araştırmacı yapıda oldukları, editörlük ve/veya köşe yazarlığı görevini yüklendiklerini belirtmişlerdir.

Çiçek (1993) gazetecilik alanında kullanılan yeni teknolojilere bağlı olarak gazetecilerin bilgi gereksinimlerinin önem kazandığını belirterek, "belge ve bilgi merkezi" adı verilen dokümantasyon ve enformasyon hizmetlerinin işleyişini açıklayan çalışmasını yapmıştır.

Nicholas ve Martin (1997) gazetecilerin bilgiyi doğrulama, güncel haberleri izleme, araştırma, metin sağlama ve toplumu yönlendirme amacıyla bilgiye gereksinim duyduklarını saptayarak bilgi kaynaklarına erişim yöntemleri ve bilgi teknolojilerinin kullanımı hakkında eğitim almanın bilgi arama davranışını olumlu yönde etkilediğini ortaya çıkarmışlardır.

Fabritius (1999), gazetecilerin bilgi arama davranışının gazetecilik kültürü, çalışılan medya alanının gelenekleri, ilgilenilen bölümün özellikleri, işlemleri uygulama yöntemleri, haberi hazırlama işlemleri, çeşitli kaynakları değerlendirme biçimleri, bilgi erişim yöntemleri doğrultusunda biçimlendiğini açıklamaktadır.

Alır (2001) haber ile ilgili araştırmaların gazetecilerin bilgi gereksinimlerini belirlediğini saptayarak bilgi arama davranışlarının sırasıyla uzmanların bilgisinden, kendi koleksiyonlarından, İnternet 
ortamındaki bilgilerden ve son 30 yıla ait haberlerden etkilendiğini ortaya çıkarmıştır.

Anwar, Al - Ansari ve Abdullah (2004) Kuveyt'te çalışan gazetecilerin haber yazmak, gelecekteki çalışmalar için yeni fikirler edinmek, gündemi izlemek ve haberde yer alacak bilgileri kontrol etmek amacıyla duydukları bilgi gereksinimlerini en kolay ve hızlı biçimde karşılama yoluna gittiklerini saptamışlardır.

\section{Gazetelerde Bilgi ve Belge Merkezler}

Güvenilir bilgi ve belgeye en kısa zamanda ulaşmak isteyen gazeteciler için bulunulan kurumdan hizmet almak büyük kolaylık sağlamaktadır. Gazetecilerin bilgi ve belge merkezlerinden geleneksel beklentileri belirli bir haber ve/veya makale isteği, soruların yanıtlanması, eldeki bilginin kontrolünün yapılması, yayınlanmış habere yönelik isteklerin karşılanması, güncel bilgi isteği, kişilerle ilgili bilgilerin saptanması, geçmiş olaylarla ilgili soruların cevaplanması, araştırmaların desteklenmesi, kullanıcı eğitimi, verilen hizmetlerin duyurulması, kullanımakta olan bilgi merkezi aracılığıyla diğer yerlerden gereksinimlerin karşılanması, fotoğraf ve grafik seçimi hakkında olmuştur (Adil, 1991, ss. 23-25; Ward, Hansen ve Mcleod, 1988, s. 145; Whatmore, 1978, ss. 41-44; Yontar, 1991, ss. 9-19). İletişim teknolojilerindeki gelişmelerin yaşama geçirilmesi gazetelerin gerek kütüphanelerinde, gerekse arşivlerinde verilen bilgi ve belge hizmetlerine yeni boyutlar kazandırmıştır. Gazetelerde kurulan bilgi ve belge merkezlerine yönelik araştırmalar arasında şunlar bulunmaktadır:

Gazetelerde kurulan kütüphanelerin İnternet ve elde bulunan kaynakların ardından geniş kullanıma sahip olduğu saptanmıştır. Kuveyt'teki gazetelerde genellikle kütüphane olarak düzenlenen bilgi merkezleri sırasıyla veri tabanlarını tarama, okuma, kütüphaneciden bilgi taraması isteme, eski gazete ve dergi sayılarını inceleme, ödünç alma, İnternet'i kullanma amaçlarına hizmet etmektedir. Araştırmaya katıların büyük çoğunluğu tarafından her gün yoğun olarak kullanılan kütüphane hizmetlerinden büyük memnuniyet duyulmaktadır (Anwar, Al-Ansari ve Abdullah, 2004, ss. 231-233).

Bilgi merkezleri Cumhuriyet gazetesinde arşiv/kütüphane (Alakuş, 1991); Gelişim Yayınlarında (Çelebiler, 1991), Günaydın (Yolcu, 1992) ve Hürriyet gazetelerinde (Alır, 2001) önce arşiv, sonra bilgi ve belge merkezi; Milliyet gazetesinde başta arşiv ve kitaplık (Özsoy, 1991), ardından belge bilgi merkezi (Alır, 2001); Zaman gazetesinde arşiv (Alır, 
2001) olarak adlandırılmıştır. Çabuk (1990), 29 gazetenin İstanbul'daki merkezlerinde bulunan kütüphane ve arşivlerin ne durumda olduğunu ortaya koymak üzere yaptığı araştırmada, 12 gazetede bu amaçla bir birim bulunmadığını, bulunanlarda ise gazete arşivi adının tercih edildiğini ve buralarda kütüphanecilik öğrenimi görmüş elemanların çalıştırıldığını, Günaydın gazetesinde 9 , Cumhuriyet gazetesinde 5 kütüphanecinin çalıştığını saptamıştır. Yapılan çalışmalarda bu merkezlerin temelde kurum personeline olmakla birlikte, dışardan gelen araştırmacılara da danışma, ödünç verme, dizinleme, eski sayılara erişim ve kupür arşivi hizmetleri verdiği anlaşılmıştır. Gazete yöneticilerinin işleri önemsemediklerinden yatırım yapılmaması sonucunda bilgi yönetiminde ve hizmetlerinde karmaşıklık ve belirsizlik yaşandığı dile getirilmiştir (Hünerli, 1991, ss. 41-42). Aralık 2006-Ocak 2007 tarihlerinde gerçekleştirilen araştırmamız, gazetelerin 1990'lardan günümüze değin yönetimsel açıdan değişimlere uğraması sonucunda geçmişte bilgi ve/veya belge merkezi olsa da, günümüzde gereksinim duyulmasına rağmen, bu merkezler açısından tasarrufa yönelim nedeniyle hizmet kalitesinde düşüşler yaşandığını saptamıştır.

\section{Gazetecilere Elektronik Bilgi Hizmetleri}

Gazetecilik alanına 1970'li yıllarda yazı ve haber hazırlamak üzere giren bilgisayarlar, 1980'lerde gazete kupürlerini elektronik ortamda dosyalama ve saklama, 1990'larda ise veri tabanı ve İnternet kullanma amaçlarıyla yaygınlık kazanmıştır (McKercher, 1995). Bilgisayar destekli gazetecilik (Computer-Assisted Journalism-CAJ ya da Computer-Assisted Reporting-CAR) yöntemleri çevrimiçi olarak elde edilebilen bilgileri, ticari bilgi hizmetlerini, Web erişimlerini, veri tabanlarının kullanımlarını, elektronik kaynaklardan yararlanmayı kapsamaktadır. Eski tarihli kaynaklara, uzmanlık alanlarına, değerlendirmelere, raporlara, görüşlere ulaşabilme imkânı yaratılmaktadır. Kişisel iletişim kurma, tarama yapma, diğer gazeteleri okuma, kendini geliştirme ve eğitim alma amaçlarına hizmet etmektedir. Elektronik bilgi hizmetleri alanında toplanan bilgiye yeniden erişememe, arşivlenmiş düzenlerin yaygınlık kazanmaması, kullanım konusunda beceri eksiklikleri, eğitim gereksinimleri, abone ücretlerinin yüksekliği gibi çeşitli sorunlar da yaşanmaktadır. Sayılan bütün kullanım alanları, yararlar ve sorunlar gerçek gazeteciliğin ne olduğu, İnternet kullanımlarının değerlendirildiği, mesleki kuralların tartışıldığı yeni araştırmalara konu olmaktadır. Kütüphaneciler ve arşivciler kendilerinden hizmet talep eden kurumlarda görev yaparak 
onların bilgi ve belge gereksinimlerini karşılamakta, eğitim vermekte, takım çalışmalarına katılmakta ve birçok konularda hizmet sunmaktadırlar. (Fabritius, 1998; IFLA, 2007b; Special Library Association, 2007).

\section{Gazetelerin Kupür Arşivleri ve Internet}

Gereksinim duyulan gazetelerin taranıp, gerekli görülen haber kupürlerinin kesilip, kupür kâğıdının üzerine yapıştırııı, plastik dosyalara yerleştirilmesiyle hazırlanmaya başlanmıştır. Teknolojik gelişmelerin yaygınlaşmasıyla kullanılan kâğıt yerini elektronik ortama bırakmıştır. Her iki ortamda da erişimi sağlayacak konu sınıflandırmasında belirli bir standart getirilmemiştir. Konular genelleştirilmemiş, özelleştirilmiştir. Kullanıcıların gereksinimleri ve olası aramalarında kullanacakları başlıklar düşünülerek düzenlemeler yapılmıştır. Kişi, konu, yazar, gazete, aramanın başlangıç tarihi, aramanın bitiş tarihi, kupür kümesi ve değişik birleşimlerle aramalar yapılmaktadır.

Türkiye gazetelerinde ilk optik kupür arşivi Günaydın Gazetesinde geliştirilen "OPAL Arşiv Sistemi" olmuştur. Böylece habere-bilgiye erişim için geleneksel yöntemlerle başlayan çalışmalar, kart katalogların hazırlanmasının ardından, bilgisayarların kullanılmasıyla hız kazanmıştır (Yolcu, 1992). Gazetede yaşanan yönetimsel değişiklikler ve teknolojik gelişmeler sistemin yenileşmesini sağlamıştır.

\section{Haber Ajanslarının Kullanımında Bilgi Merkezler}

Dünyada 1835 yılında Havas Haber Ajansı'yla başlayan çalışmaların öncüleri arasında Associated Press (AP) ve Reuters bulunmaktadır (Tokgöz, 2006, ss.105-111). Türkiye'nin ilk haber ajansı 1911 yılında kurulan ve kısa sürede kapanan Osmanlı Telgraf Ajansı olmuştur. Bunu yine kısa ömürlü olan Milli Ajans izlemiştir. 6 Nisan 1920 tarihinde Mustafa Kemal Atatürk tarafından kurulan Anadolu Ajansı 1 Mart 1925'de "anonim şirket" yapısıyla gelişim göstermiştir. Anadolu Ajansı'nın yurtiçinde 28 bölge ve büro müdürlüğü, yurtdışında 22'si temsilcilik olmak üzere 30 merkezde muhabirleri bulunmaktadır. Yurda ve dünyaya yayılan muhabirlerinin ürettiği günde ortalama 700 haberi aboneliklerine ulaştırmaktadır (Anadolu Ajansı, 2007). 1972 yılında Ankara Haber Ajansı-ANKA (2007), 1993 yılında İhlas Haber Ajansı- İHA (2007), 1981 yılında Magazin ve Aktüel Haberler Ajansı-MAK (2007) kurulmuştur. Bilgi merkezleri haber ajanslarından yapılacak taramaların öğretilmesinde yol gösterici ve eğitici olmaktadırlar. Gerektiğinde alınan haberin 
arşivlenmesini ve erişim için işlemlerin gerçekleştirilmesini sağlamaktadırlar.

\section{Gazeteleri Mikro Forma ve/veya Dijital Ortama Aktarma Projeleri}

Geçmişi yaşatmak amacıyla günümüzden geçmişe doğru gazeteler elektronik ortama aktarılmakta ve erişimi sağlayacak yöntemler geliştirilmektedir. Genellikle milli kütüphaneler veya geniş gazete koleksiyonu bulunduran kütüphaneler tarafından gazeteler 1950'lerden itibaren mikro formlara, özellikle mikrofilme geçirilmiş, 1990'lardan itibaren de elektronik ortama aktarma projeleri yürütülmeye başlanmıştır. Bazı örnekler şunlardır:

TIDEN (The Nordic Digital Newspaper Library): 1998'de başlayan projeyle 1640 - 1890 yıllarında Finlandiya'da yayınlanan tüm gazetelerle İsveç, Norveç, Danimarka ve İzlanda'dan 3'er gazeteyle birlikte ilgili ülkelerden sorumlu kütüphanelerin belirlenmesiyle çalışmalar yürütülmüştür. Genellikle 1950'lerden bu yana mikrofilme geçirilmiş gazetelerin dijital ortama aktarılması, resimlerin yazı dosyasına dönüştürülmesi, erişimi sağlayacak işlemlerin tamamlanması, veri tabanı oluşturulması ve uluslararası gelişmelerin izlenmesi sonucu 2001 yılından itibaren kullanıcılara açılmıştır. Kapsamı genişlemekte olup hizmetler ücret karşılığında verilmektedir (Bremer-Laamanen, 2005; TIDEN, 2007).

BN (British Newspapers) Projeleri: İngiltere'de 1822 tarihinden itibaren British Museum tarafından gazeteler sistemli bir şekilde toplanmaya başlanmıştır. Gazetelere yönelik özel depo 1905 yılında hazırlanarak 1932'de kullanıcıların hizmetine sunulmuştur. Savaş yıllarında hizmet binaları zarar görmekle birlikte, 1950'lerden itibaren gazeteleri mikrofilme geçirme çalışmaları yürütülmüştür. 1973 yılında British Museum'un bütün gazete koleksiyonu İngiliz Milli Kütüphanesine devredilmiştir (British Library, 2007a). 1980'li yılların başından bu yana İngiliz Milli Kütüphanesinde bulunan gazetelerle birlikte Galler, İngiltere, İrlanda ve İskoçya kapsamlı gazeteler dijital ortama geçirilmektedir. Tarihi gazetelere yönelik "British Library British Newspapers 1800-1900 Project" (Shaw, 2005) ve gazete haberlerine yönelik NEWSPLAN (The British Library, 2007b) projeleri hayata geçirilmiş olup, gelişmeler devam etmektedir. 


\section{Diğer Hizmetler}

Bilgi merkezlerinde gazetelere yönelik hizmetler arasında tarihsel araştırmaları destekleme, koleksiyon geliştirme, bölgesel yayınları listeleme, gazete haberlerini kataloglama, gazete kütüphanelerinde ödünç verme kurallarını saptama, uluslararası işbirliğini geliştirme, haber ve yayıncılık etkileşimleri, bilgi-belge hizmetleri konusunda eğitim programları hazırlama, telif hakları, standart geliştirme, koruma ve saklama yöntemlerini belirleme, dijital gazete kütüphaneleri, geleceğe yönelik çalışma alanlarını planlama ve diğer birçok konular bulunmaktadır (Campbell, 1997; Nicholas, Williams, Cole ve Martin, 2000; Walravens, 2006; Walravens ve King, 2003; Whitlam ve Preston, 1998). Sayılan konuların her birini ayrı araştırma alanı olarak tanımlamak mümkündür.

\section{Bilgi Merkezlerinde Gazetelere Yönelik Hizmetlerin Araştırılması}

\section{Amaçlar}

Burada yer alan çalışma kapsamında gerçekleştirdiğimiz araştırmanın amacı gazetelerin bünyesinde bilgi merkezlerinin nasıl yapılandığını ve kullanıldığını saptamaktır. Bir başka deyişle haberleri buluşturan gazetelerle ilgili kuruma, meslek grubuna ve topluma verilen hizmetleri ortaya çıkararak ve bu konuda bilgi vererek ülkemizdeki gelişmelere yol göstermeye çalışmaktır. Sayılan bu amaçlar günümüzün haberinin, gelecekteki erişimini yansıtacaktır.

\section{Araştırmanın Alanı, Kapsamı ve Yöntem}

Araştırmamızı ilgilendiren uygulamaları yerinde görmek amacıyla Aralık 2006 ve Ocak 2007 tarihleri arasında rastgele seçilen gazetelerin Ankara temsilciliklerine gidilerek onların bilgi - belge merkezlerindeki görevlileriyle görüşmeler yapılmıştır. Amaçlarımız doğrultusunda Cumhuriyet, Hürriyet, Milliyet, Radikal, Sabah ve Zaman gazetelerinde betimleme yöntemine uygun olarak araştırmamız gerçekleştirilmiştir. Betimleme yöntemi: “...olayların, varlıkların, kurumların, grupların ve çeşitli alanların ne olduğunu betimlemeye, açıklamaya çalışan incelemelerdir. Bunlar nedir? Sorusuna cevap bulmaya yöneliktir. Bununla mevcut durumlar, koşullar, özellikler aynen ortaya konmaya çalışılır. Betimleme araştırmaları, mevcut olayların daha önceki olay ve koşullarla ilişkilerini de dikkate alarak, durumlar arasındaki etkileşimi açıklamayı hedefler" (Kaptan, 2000, s. 59). 
Araştırma için gerekli olan veriler literatür incelemesi, görüşme ve gözlem tekniğinden yararlanılarak elde edilmiştir. Temelde iki sorudan oluşan görüşme sorularının cevaplandırılması öncesinde ve sonrasında gözlem yapılarak bulunulan ortam tanımlanmıştır.

\section{Araştırmanın Uygulanması}

Türkiye'de gazetelerin genel yapılanması incelendiğinde bilgi ve belge merkezlerinin İstanbul'da toplandığı görülmektedir. Bu gazetelerin Ankara'da "Başkent" temsilcilikleri bulunmaktadır.

Araştırma kapsamındaki Cumhuriyet gazetesi 7 Mayıs 1924'de Yunus Nadi Abalıoğlu; Hürriyet gazetesi 1 Mayıs 1948'de Sedat Simavi; Milliyet gazetesi 3 Mayıs 1950'de Ali Naci Karacan; Radikal gazetesi 1996'da Aydın Doğan; Sabah gazetesi 22 Nisan 1985'de Dinç Bilgin; Zaman gazetesi 3 Kasım 1986'da Alaattin Kaya, Fehmi Koru, Nabi Alıcı ve İhsan Arslan tarafından kurulmuştur. Gazetelerin merkezleri İstanbul'da bulunmakta olup, hepsinde bilgi merkezi kurulmuş ve mesleki personel görevlendirilmiştir. Bu merkezlerde eski yayınlar ciltlenmekte; fotoğraf, slayt ve kupür arşivleri düzenlenmekte; konu başlıkları, kupür ve görsel malzeme dosyaları ve haber dizini hazırlanmakta; İnternet üzerinden gazetelerle ilgili arşiv hizmetleri sunulmaktadır. Gazetelerin çok sayıda uluslararası ve ulusal haber ajanslarına aboneliklerinin olması, haber sağlamayı kolaylaştırdığını düşündürmektedir. Ankara'da gerçekleştirilen araştırmamızın görüşmelerinde yöneltilen sorular şunlardır:

> Gazetelerde bilgi ve belge merkezi olarak düzenlenen yapılanmanın özellikleri nelerdir?

> Bilgi hizmetlerinin kullanım düzeyi nedir? Bunlar haberlerin geleceğiyle nasıl bütünleştirilebilir?

Birinci soruda belirtilen gazetelerin Ankara'daki "Başkent" temsilciliklerinde bilgi ve belge hizmeti vermek üzere özel yapılanmanın gerçekleşip, gerçekleşmediği saptanmak istenmiştir. Alınan yanıtların tamamından, gazetelerin bilgi ve belge hizmeti vermek üzere özel bir yapılanmaya gitmedikleri, bilgi merkezi oluşturmadıkları görülmüştür. Ancak bu gazetelerde acil gereksinimleri karşılamak üzere eski gazeteleri barındıran bilgi merkezi isimli depo bulunmaktadır. Sadece Hürriyet ve Zaman gazeteleri geçmişlerinde birer kütüphaneciyi görevlendirmişlerdir. Araştırmamızın gerçekleştiği dönemde kütüphanecilerin görevde olmadığı kaydedilmiştir. Yayın grupları bünyesinde ve ilgili yayın grubunun bütün 
medya ürünlerini birleştiren fotoğraf ve metin arşivleri düzenlenmiştir. Kuruluşlarında kâğıt temel alınarak elci yöntemlerle yürütülen işlemler mikro form teknolojilerinin kullanılmasıyla değişim göstermiştir. Böylelikle 1980 öncesinde yayın hayatına başlayan üç gazetenin (Cumhuriyet, Hürriyet ve Milliyet) büyük yer tutan eski sayılarına yönelik yer ve erişim sorunları çözümlenmiştir.

İkinci soruda bilgi hizmetlerinin kullanımı saptanmaya çalışılmıştır. Bunların bilgi erişimi ve haberin geleceğini nasıl etkilediği ortaya çıkarılmak istenmiştir. Bilgi merkezi görevlileri, gazetecilerin araştırmamızda da tanımladığımız bilgi erişim kaynaklarından ve hizmetlerinden sırasıyla İnternet ve veri tabanlarını, haber ajanslarını, kupür arşivlerini kullandıklarını ifade etmişlerdir. Gazetelerin tamamında 1990'lı yıllardan günümüze, gazete işlemleriyle bağlantılı olarak bilgi, belge hizmetlerinde bilgisayar kullanımı büyük imkânlar sağlamıştır. Böylece eski sayılara erişim, işlemler ve hizmetler kolaylaşmıştır. Ancak kullanımların sayısal değerlendirmesi yapılmamıştır. Gazetelerde mesleki eğitim almış bilgi ve belge yöneticisi bulunmamakla birlikte bu durum, bilgi merkezlerine duyulan gereksinimleri ortadan kaldırmamıştır. Günümüzün haberlerine bugün olduğu gibi ve gelecekte de erişim sağlamak üzere yapılan çalışmalar bilgi-belge hizmetleriyle bütünleştirilememiştir.

Görüşmelerimizde, bilgi merkezi olarak adlandırılan depo nitelikli yerlerde "yukarıda yer alan çalışmalarımız boyunca tanımladığımız işlemleri gerçekleştirecek yapılanma" ve bunlara bağlı olarak "kullanımlar" saptanamamıştır.

\section{Değerlendirmeler}

Araştırmamızda elde edilen bulgular ışığında yaptığımız değerlendirmeler, verilen yanıtların yüzdesi (parantez içinde gösterilmiştir) ve ulaştığımız sonuçlar aşağıda belirlenmiştir:

1. Belirtilen gazetelerin Ankara'daki "Başkent" temsilciliklerinde bilgi merkezlerine ve hizmetlerine gereksinim duyulmaktadır (\% 100).

2. Gazetecilerin sahip olduğu özel arşivler kurulması beklenen bilgi merkezlerine engel olacağı düşünülmemektedir (\% 100).

3. Gazetecilerin mesleki eğitim almış bilgi ve belge yöneticisiyle kuracağı iletişim yardımıyla gereksinim duyulan bilginin ifade edilmesinin kolaylaşacağı ve belirsizliklerden kurtulmanın mümkün olacağı belirtilmektedir (\% 83,3).

4. İstanbul'daki gazete merkezlerinde gerçekleştirilen kütüphane ve arşiv yapılanmasıyla Ankara'daki "Başkent" temsilciliklerinde 
kurulan bilgi merkezleri arasında teknik bağlantılar dışında bilgi hizmetlerinde işbirliği bulunmamaktadır $(\% 83,3)$.

5. Elektronik ortamdan elde edilebilen her türlü kaynak ve hizmet için gazetecilerin bilgi merkezi olarak adlandırılan birimlere gelmeleri gerekmemektedir (\% 100).

6. Hızlı ve güvenilir bilgiye erişimde gazetelerin bilgi ve belge merkezleri rehberlik yaptıklarından önemleri artmaktadır $(\% 83,3)$.

7. Gazetelerin bilgi ve belge merkezlerinde mesleki yapılanmaya uygun düzenlemelerin gerçekleşmesiyle hizmet kalitesinin artacağı düşünülmektedir (\% 66,6).

8. Gazete bünyesinde bilgi merkezine ve hizmetlerine duyulan gereksinimle, bu merkezlerin hizmetleri için kaynak ayrılmaması birbirleriyle tezat oluşturan sorunları ortaya çıkarmaktadır (\% 66.6).

9. Gazete yönetimleri bilgi ve belge hizmetleri konusunda yeterince aydınlatılmadıklarından, gereken planlamayı gerçekleştirememektedirler (\% 50).

10. Gazetecilerin bilgi gereksinimleri ve bilgi kullanım özellikleri konusunda yapılacak araştırmalarla, var olan bilgilerin güncelleştirilmesi beklenmektedir (\% 83,3).

\section{IFLA Planları Kapsamında Geleceğe Yönelik Hizmetler ve Beklentiler}

Gazetelere yönelik bilgi ve belge hizmetleri konusu bilgi yönetimi alanının öncü nitelikli uluslararası mesleki derneği IFLA'nın çalışma alanlarına girmiştir. Özel çalışma alanı olarak "gazeteler bölümü" kurulmuştur. Belirtilen yapılanmayla çeşitli bilgi merkezlerinde bulunabilen gazetelerin toplanması, koleksiyonlar oluşturulması, düzenlenmesi, içerik analizlerinin yapılması, erişimin sağlanması, depolanması, korunması ve saklanması, gereksinimlere uygun biçimlere dönüştürülmesi, işbirliği çalışmaları, ödünç verme işlemleri, dijital teknolojilerin etkisi, mesleki gelişmelerin izlenmesi ve sorunların çözümlenmesi yolunda görevler yüklenilmiştir. Örgütsel yapı, kuramsal gerçekler ve uygulamalar çerçevesinde ortaya çıkan sorunlara çözüm sağlamak üzere IFLA tarafından belirlenen 6 temel çalışma başlığı altında gerçekleştirilecek planlar, görevler ve ulaşılmak istenilen hedefler şunlardır (IFLA, 2007c):

1. Büyük gazete koleksiyonlarının dünya çapında kullanımını sağlayacak bilgi alışverişinin gerçekleştirilmesi; 
2. Gazetelere ilişkin koruma, mikrofilme çekme ve dijitalleştirme programlarında uluslararası standartların geliştirilmesi ve uygulamaların teşvik edilmesi;

3. Gazetelerin basımını, dağıtımını, arşivlenmesini, erişimini ve kütüphane hizmetlerinin verilmesini etkileyen teknolojik gelişmelerin izlenmesi;

4. Kütüphanelerin ve arşivlerin bilgi kaynağı olarak gazeteleri sağlama işlemlerine yönelik fırsatların yaratılması;

5. Bibliyografik kontrolü, kataloglamayı ve bilginin organizasyonunu gerçekleştirmek üzere var olan rehberlerin geliştirilmesi;

6. Gazetelere yönelik bilgi hizmetlerinde işbirliği ve bilgi paylaşımının sağlanması.

Geliştirilen projelerle, araştırmalara dayanan yayınlarla, mesleki iletişimi sağlayan gazetelerin yayınlanmasıyla, düzenlenen toplantı ve konferanslarla dünya çapında başarılı çalışmalar sürdürülmektedir. Konuyla ilgili araştırmacılar ve bilgi-belge yöneticileri için önemli bir danışma kaynağı olarak "Gazete Koleksiyonları Rehberi" hazırlanmıştır. $\mathrm{Bu}$ rehberde çeşitli ülkelerden gazete ve haber kullanımını mümkün kılan bilgi merkezlerinin adları, adresleri ve kullanım bilgileri sunulmaktadır. Türkiye'den Milli Kütüphane'nin yer aldığı bu rehber, eklenen ve çıkarılan bilgilerle güncel tutulmaya çalışılmaktadır (IFLA, 2007a). Benzer şekilde gazetelere yönelik elektronik kaynaklara ve verilen hizmetlere ilişkin tanıtım yapılarak aktif çalışmalar sürdürülmektedir (IFLA, 2007b).

\section{Genel Değerlendirme}

19. yüzyıldan başlayarak sayıları ve türleri büyük artış gösteren gazeteler tarih, politika, sosyoloji, eğitim, ekonomi, sanat, iş dünyası, tabii bilimler, sağlık, güvenlik, teknoloji ve kısaca birçok bilim alanında insanlık için önemli bilgi kaynağı olarak kabul edilmektedir. Bilgi merkezlerinde gazetelere yönelik hizmetlerin temelinde ilgili kullanıcı grubu ile bilgi kaynakları arasında köprü oluşturma isteği yatmaktadır. Gazetelere ve onun içeriği olarak kabul edilen habere ilişkin hizmetlerin 5 temel yapıda düzenlendiği ortaya çıkmıştır. Bunlar şöyle biçimlenmektedir:

1. Medya kuruluşları içinde kurulan gazete kütüphaneleri veya haber arşivleri;

2. Gazete kütüphanesi veya arşivi olarak kurulan özel bilgi merkezleri;

3. Gazete koleksiyonlarını barındıran çeşitli türlerdeki kütüphaneler ve arşivler; 
4. Haber ve/veya gazete kapsamlı elektronik bilgi hizmetlerini içeren yapılanmalar;

5. Yukarıda sayılan yapılanmaların iki veya daha fazlasını birleştiren düzenlemeler.

Gerek çeşitli bilgi merkezlerinde, gerekse gazetelerin kendi bünyelerinde kütüphane ve/veya arşiv olarak kurdukları merkezlerde sunulan hizmetlerin gazetelere, gazeteciliğe, muhabirlere ve medya kitle iletişim araçlarının hazırlanmasına katkıları şunlar olmaktadır:

1. Zihinsel ve düşünsel fikir ürünlerinden oluşan yazılı, basılı, görsel işitsel ve elektronik ortamdaki çeşitli bilgi kaynaklarından farkında olma, kullanma ve sürekli erişim imkânları sağlanmaktadır.

2. Gazetelere ait eski sayıların depolanmasına, korunmasına ve erişilmesine yönelik hızlı ve güvenilir hizmetler verilmektedir.

3. Gereken bilgi kaynaklarına ve/veya konulara yönelik kataloglama, sınıflama, dizinleme, özetleme ve benzeri ikincil kaynakların üretilmesiyle habere ilişkin acil bilgi gereksinimleri kolaylıkla karşılanmaktadır.

4. Geçmişe yönelik bilgi ve belgeye erişimle birlikte kullanımı ve geleceğe yönelik temel oluşumları sağladığından başarılı gazetecilik hizmetlerine vazgeçilmez katkılarda bulunmaktadır.

5. Yeni yetiştirilen gazetecilere çalışılan kurumun geçmişi, bugünü ve geleceği hakkında temel bilgiler kazandıran ve eğiten merkez görevi görmektedir.

6. Gazetecilere bilgi erişimde kolaylıklar sağlayacak yöntemlerden farkında olma, İnternet ortamında bulunan kaynakları keşfetme ve bilgi erişimde yol gösterici olabilme nitelikleri bilgi-belge uzmanlarının çalışmalarıyla kazandırılmaktadır. Kütüphanecilerin veya arşivcilerin eğitimci yönünün ortaya çıkarılmasıyla sağlanabilen bu başarılar, düzenlenecek eğitim programlarının yaşama geçirilmesiyle, geniş bilgi evreninden gereksinim duyulan bilgiye erişimi sağlamaktadır.

Gazetecilerin erişebildikleri bilginin miktarı, özelliği, yeterliliği ve zamanı; önce haberin, ardından gazetenin kalitesini etkilemektedir. Gazetelerin bilgi ve belge merkezleri hizmet verdikleri başta gazeteciler olmak üzere bulundukları kurumun bilgi gereksinimlerinin karşılanması konusunda büyük sorumluluklar yüklenmektedirler. Kütüphanecilik ve arşivcilik mesleğinin ilkeleri çerçevesinde, gazetecilerin bilgi 
gereksinimleri doğrultusunda düzenlenecek bilgi ve belge merkezleri bilgiden sınırsız yararlanmanın en önemli desteği olacaktır.

\section{Sonuç}

Haberin geleceği her anlamda yeniliğin, değişimin, iletişimin ve etkileşimin ifadesi olmaktadır. Günümüzdeki özellikleriyle birlikte, haberin gelecekte özelliğine göre geniş kapsamlı ya da özet halinde hazırlanmış, her ortamdan değişik alet kullanımlarıyla erişilebilir, kolay anlaşılabilir, katılımcı, hazırlanmasına büyük özen gösterilmiş, doğru ve güvenilir olması beklenmektedir. Çeşitli ortamlarda yayınlanabilen haber, gazetelerde yer aldığında da özelliklerini sürdürecektir. Haberin geleceği; daha az kişinin emeğiyle hazırlanmış, boyutları küçük, etkisi büyük, ilgi çekici, özel konularda hazırlanmış, İnternet yardımıyla indirilebilen, diğer medya ürünleriyle bağlantılı, hızlı, etik ilkelere inanan ve önemli araştırmaları içeren geleceğin gazeteleriyle bütünleşecektir. Doğal olarak haberlerin ve gazetelerin hazırlanması takım çalışmalarını gerektirecektir.

$\mathrm{Bu}$ çalışmada, haberin geleceğinin, önce yayınlandığı bilgi kaynağında, incelediğimiz kapsamda gazetede, ardından gazetelere ve haberlere yönelik çok çeşitli hizmetleri yapılandıran ve kullanıma sunan bilgi-belge merkezlerinde biçimlendiği ortaya çıkmıştır. Günümüzün haberinin, gelecekte tekrar haber hazırlamada, özellikle araştırmaya dayalı ve geçmişe yönelik açıklayıcı bilgi veren haberlerin hazırlanmasında kullanılabileceği bir gerçektir. İşte bu durumun mümkün olabilmesinde gazetelerde ve gazetelere yönelik verilen çeşitli "bilgi ve belge hizmetlerinin yapılanması ve kullanımı" büyük katkılar sağlayacaktır. Araştırmamız; kişi ve kuruluşların yapılandırdığı çeşitli hizmetler olsa da, bilgi merkezlerinin var olan bütün hizmetlerden gazetecilerin farkında olmasına, kullanmasına, haber hazırlamasına ve yayınlar üretmesine önemli katkılar sağlayan merkezler olduğunu verilen örneklerle göstermiştir. Kütüphaneciler ve arşivciler çeşitli ortamlarda ve biçimlerde haberlerin geleceğine yönelik hizmetler planlamaya devam etmektedirler. Araştırmamızı gerçekleştirdiğimiz gazeteler başta olmak üzere, gazetecilere yönelik bilgi ve belge hizmetlerinin düzenli olarak yapılanmadığı ve öneminin Türkiye'de yeterince anlaşılmadığı belirlenmiştir. Genellikle haberlerde güvenilirliğin, doğruluğun, uzmanlığın ve kapsamlı değerlendirmeleri içeren yorumların sorumlusunun gazetecibasın mensubu olacağı bilinmektedir. Tarih boyunca süregelen uzmanlık alanlarındaki bilgi gereksinimlerini en verimli şekilde karşılama isteği çeşitli bilgi merkezlerinin kurulmasını sağlarken, günümüzdeki teknolojik 
gelişmeler bu merkezlerde verilen hizmetlerin sınırlarını ortadan kaldırmıştır.

Geleneksel yöntemleri, elektronik hizmet ortamlarıyla geliştiren kütüphaneler, haber ve gazete arşivleri bugünkü haberin yarına kolaylıkla ulaşmasını ve erişilmesini sağlayan geleceği olmuştur. Bilgi merkezleri geçmişte ve günümüzde olduğu gibi gelecekte de haberlere yönelik hizmetler vermeyi hedeflemektedirler. Bilgi hizmetlerine yönelik olarak gazetelerin yönetimsel yapılarında önemli değişiklikler yaşanmakta, bilgi merkezlerinin her gazetede yapılanması mümkün olmamaktadır. Bilgi ve belge uzmanları sadece kütüphane veya arşiv olarak tanımlanmış bilgi merkezlerinde değil, haberlerin araştırılmasında ve hazırlanmasında görev yapan gazetecilerden-muhabirlerden oluşan takımların aktif üyeleri olarak görev yapmaları gerekmektedir.

Bilgi merkezleri verdikleri hizmetlerle haberleri geleceğe ulaştıran çalışmalarını yürütmektedirler. Haberciliği, gazeteciliği, bilgi ve belge hizmetlerini bütünleştiren araştırmaların yapılmasıyla haberin ve bilginin sonsuz paylaşımı gerçekleşecektir.

\section{Kaynakça}

Adil, İ. (1991). Gazeteci gözüyle gazete kütüphaneleri. H. S. Keseroğlu (Yay. Haz.). Gazete kütüphaneciliği ve Türkiye içinde (ss. 23-26). İstanbul: Türk Kütüphaneciler Derneği İstanbul Şubesi.

Alakuş, M. (1991). İletişim araçları. H. S. Keseroğlu (Yay. Haz.). Gazete kütüphaneciliği ve Türkiye içinde (ss.45-57). İstanbul: Türk Kütüphaneciler Derneği İstanbul Şubesi.

Alır, G. (2001). Türk basınında bilgi erişim sorunları. Yayınlanmamış bilim uzmanlığı tezi, Hacettepe Üniversitesi, Ankara.

Anadolu Ajansı. (2007). Haberin kaynağından. 22 Şubat 2007 tarihinde http://www.anadoluajansi.com.tr/ adresinden erişildi.

Ankara Haber Ajansı-ANKA. (2007). ANKA Haber Ajansı. 22 Şubat 2007 tarihinde http://www.ankaajansi.com.tr/index.php adresinden erişildi.

Anwar, M. A., Al-Ansari, H. ve Abdullah, A. (2004). Information seeking behaviour of Kuwaiti journalists. Libri, 54 (4): 228-236.

Bodur, F. (1997). Yerel basında yönetim ve örgüt yapısı. Eskişehir: Açıköğretim Fakültesi.

Bremer-Laamanen, M. (2005). Connecting to the past-newspaper digitisation in the Nordic countries. 27 Şubat 2007 tarihinde http://www.ifla.org/VII/s39/39pconf.htm adresinden erişildi. 
British Library. (2007a). Newspapers digitisation project: British newspapers 1800-1900. 27 Şubat Ocak 2007 tarihinde http://www.bl.uk/collections/britishnews1.html adresinden erişildi.

British Library. (2007b). Newsplan. 8 Ocak 2007 tarihinde http://www.bl.uk/cgi-bin/print.cgi?url=/collections/nplan.html adresinden erişildi.

Campbell, F. (1997). Journalistic constructionof news: Information gathering. New Library World, 98 (1133): 60-64.

Çabuk, H. (1990). Gazete kütüphaneleri: istanbul'da bir gözlem. Yayınlanmamış bilim uzmanlığı tezi, İstanbul Üniversitesi, İstanbul.

Çelebiler, Ö. (1991). Gelişim Yayınları Belge-Bilgi Merkezi'nde bilgisayara geçiş dönemi. H. S. Keseroğlu (Yay. Haz.). Gazete kütüphaneciliği ve Türkiye içinde (ss. 67-70). İstanbul: Türk Kütüphaneciler Derneği İstanbul Şubesi.

Çiçek, N. (1993). Gazete işletmelerinde belge-bilgi hizmetleri. Yayınlanmamış bilim uzmanlığı tezi, İstanbul Üniversitesi, İstanbul.

Fabritius, H. (1999). Information seeking behaviour of journalists. 27 Şubat 2007 tarihinde http://www.uta.fi/ lihafa/jan99sem.html adresinden erişildi.

Folcarelli, R. J. (1982). The Microform connection: A basic guide for libraries. New York: Bowker.

GARILDI. (2007). Gazete Arşivi Arama Motoru. 22 Şubat 2007 tarihinde http://www.garildi.com.tr adresinden erişildi.

Gaillard, P. (1991). Gazetecilik. (M.S. Şakiroğlu, Çev.). İstanbul: İletişim Yayınları.

Gamble, M. V. ve Gamble, T. K. (1989). Introducing mass communication. New York: McGraw Hill Book.

Garrison, B. (1998). Computer assisted reporting. Mahwah, NJ. Lawrence Erlbaum Assoc Inc.

Haberbank. (1988). Haberbank. Ankara: Ekonomik Rehber Yayınları.

Haberbank. (1995). Haberbank. Ankara: Ekonomik Rehber Yayınları.

Haberbank. (2007). Haberbank: 365 Gün 24 Saat. 22 Şubat 2007 tarihinde http://www.haberbank.com/ adresinden erişildi.

Herron, N.L. (1986). Information seeking behavior and the perceptions of information channels by journalist of two daily metropolitan newspapers. Yayınlanmamış doktora tezi. University of Pittsburgh, Ann Arbor, MI . UMI Number: 8702068.

Hünerli, S. (1991). Basın müzesi kütüphanesi ve bir öneri. H. S. Keseroğlu (Yay. Haz.). Gazete kütüphaneciliği ve Türkiye içinde (ss.39-42). İstanbul: Türk Kütüphaneciler Derneği İstanbul Şubesi. 
IFLA. Newspapers Section. (2007a). Directory of newspaper collections. 22 Şubat 2007 tarihinde http://www.ifla.org/VII/s39/dir/directory.htm adresinden erişildi.

IFLA. Newspapers Section. (2000b). Newspaper electronic resources. 22 Şubat 2007 tarihinde http://www.collectionscanada.ca/informationmanagement/index.html ve http://www.bl.uk/collections/newspapers. $\mathrm{html \# Electronic} \mathrm{adreslerinden} \mathrm{erişildi.}$

IFLA. Newspapers Section. (2007c). Strategic plan 2006-2007. 22 Şubat 2007 tarihinde http://www.ifla.org/VII/s39/annual/sprtnews.htm adresinden erişildi.

IFLA. Newspapers Section. (1993-). Newsletters. 18 Aralık 2006 tarihinde http://www.ifla.org/VII/s39/index.htm adresinden erişildi.

İhlas Haber Ajansı (2007). İhlas Haber Ajansı. 22 Şubat 2007 tarihinde http://www.iha.com.tr/bin/directory.dll/pf adresinden erişildi.

İnuğur, M.Nuri. (2002). Basın ve yayın tarihi. İstanbul: Der Yayınları.

Kaptan, S. (2000). Bilimsel araştırma ve istatistik teknikleri. (12. bs.). Ankara: Bilim Yayınları.

Krumenaker, L. (2000). "Check em all!", 27 Şubat 2007 tarihinde http://www.infotoday.com/searcher/may00/krumenaker\&hurst.htm adresinden erişildi.

Library and Information Science Abstract. (1969- ). New York: Silver Platter.

Magazin ve Aktüel Haberler Ajansı- MAK (2007). MAK Ajans. 22 Şubat 2007 tarihinde http://www.makajans.com/index.php adresinden erişildi.

McKercher, C. (1995). Computers and reporters. Canadian Journal of Communication, 20(2): 20-32.

Nicholas, D. ve Martin, H. (1997). Assesing information needs: A case study of journatists. Aslib Proceedings, 49(2): 43-52.

Nicholas, D., Williams, P., Cole, P. and Martin, H.(2000). The impact of the Internet on information seeking in the media. Aslib Proceedings, 52(3): 98-114.

Özsoy, A. (1991). Milliyet Gazetesi arşiv ve kitaplığı. H. S. Keseroğlu (Yay. Haz.). Gazete kütüphaneciliği ve Türkiye içinde (ss. 61-63). İstanbul: Türk Kütüphaneciler Derneği İstanbul Şubesi.

ProQuest Dissertations and Thesis. (1980- ): Michigan: Proquest Company.

Semonche, P. B. (1998). Newspaper indexing policies and procedures. 27 Şubat 2007 tarihinde http://parklibrary.jomc.unc.edu/collections.html adresinden erişildi.

Shaw, J. (2005). 10 Billion words: The British Library British Newspapers 1800-1900 Project. $27 \quad$ Şubat 2007 tarihinde http://www.ifla.org/VII/s39/39pconf.htm adresinden erişildi. 
Special Libraries Association. (2007). About the news division. 21 Şubat 2007 tarihinde http://www.ibiblio.org/slanews/ adresinden erişildi.

Smith, G. (1995). Access to newspaper collections and content in a time of change. IFLA Journal, 21(4): 282-286.

TIDEN. (2007). A Nordic digital newspaper library. 8 Ocak 2007 tarihinde http://tiden.kb.se/ adresinden erişildi.

Tokgöz, O. (2006). Temel gazetecilik. Ankara: İmge Kitabevi.

Türkiye Bibliyografyası. (1935- ). Ankara: Milli Kütüphane Başkanlığı.

Türkiye Makaleler Bibliyografyası (1952- ). Ankara: Milli Kütüphane Başkanlığı.

Yolcu, E. (1992). Günaydın Gazetesinde belge-bilgi depolama ve opal arşiv sisteminin kullanımı. Yayınlanmamış bilim uzmanlığı tezi, İstanbul Üniversitesi, İstanbul.

Yontar, A. (1991). Danışma kaynakları açısından gazete kütüphaneleri. H.S. Keseroğlu (Yay. Haz.). Gazete kütüphaneciliği ve Türkiye içinde (ss. 9-19). İstanbul: Türk Kütüphaneciler Derneği İstanbul Şubesi.

Yüksel, E. ve Gürcan, H. İ. (2001). Habercinin el rehberi. Eskişehir: Anadolu Üniversitesi Yayınları.

Walravens, H. (ed.). (2006). International newspaper librarianship for the 21st century. München: Saur.

Walravens, H. ve King, E. (Ed.). (2003). Newspapers in international librarianship. München: Saur.

Ward, J., Hansen, A.K. ve McLeod, D.M. (1988). The news library's contribution to newsmaking. Special Libraries, 79(2): 143-147.

Whatmore, G. (1978). The modern news library. London: The Library Association.

Whitlam, S. ve Preston, H. (1998). Sports journalism as an information resource: A case study. New Library World, 99(1143): 194-204. 